\title{
Study of Javanese Script Writing Learning in Senior High Schools in Boyolali Regency
}

\author{
B Setiawan', P A W Wibowo ${ }^{2}$, F Azzahrah ${ }^{3}$, P R Harjani ${ }^{4}$, K Saddhono ${ }^{5}$ \\ $\left\{{ }^{1}\right.$ kaprodipbi@staff.uns.ac.id, ${ }^{2}$ prasetyoadiwisnuwibowo@yahoo.co.id, ${ }^{3}$ fatiaazzahrah@gmail.com, \\ 4harjani.puput@gmail.com, ${ }^{5}$ kundharu_s@staff.uns.ac.id\} \\ 1,2,3,4,5 Universitas Sebelas Maret Surakarta, Indonesia
}

\begin{abstract}
The implementation of Javanese language learning is one of the activities to guide and preserve Javanese language, literature and scripts. However, there are still problems such as understanding the rules of writing Javanese script, the number of vocabulary words needed to be able to read Javanese script, the presence of students from outside Central Java, East Java, and Yogyakarta. The purpose of this study was to describe the implementation of learning to write Javanese script at the high school level along with solving related problems. This study uses a qualitative descriptive method with a case study approach. The location of this study took place at SMA N 1 Ngemplak. The results of this study indicate that the problem of implementing Javanese script writing learning is overcome by the existence of good planning and evaluation from the teacher and the active role of students in learning. The implications of this study are useful as material for evaluation in the implementation of Javanese language learning in senior high school.
\end{abstract}

Keywords: Javanese Script, Writing Skill, Learning, Boyolali

\section{INTRODUCTION}

Javanese language learning in the madrasa has several materials where the material is used as a means of preserving culture, language, literature and scripts in Central Java. Some of the material taught in Javanese subjects such as macapat songs, wayang stories, folktales, traditional ceremonies, regional arts, basic uploads, geguritan, Aksara Jawas and some other material have the same functions and objectives that are nothing but introducing preserve Javanese culture, language, literature and scripts to students. The learning carried out at the madrasa has been carried out optimally in accordance with the situation and conditions in each madrasa. Various methods such as the use of methods, learning strategies, learning techniques, and learning media are applied so that implementing Javanese language learning can run optimally. During the learning process various rewards are given to some of the best students in learning. It also aims to increase the enthusiasm and motivation of students in learning activities.

The preservation of Javanese culture does not stop only in class or school. Efforts to preserve Javanese culture must be carried out continuously so that the introduction and preservation of culture, language, literature and scripts are not interrupted until just at school. Preservation activities in schools need to be balanced with other activities outside of learning, such as some studios, the role of social media, competitions or competitions can be used as additional means, to accommodate the ends of the learning process in school. 
Like the Madrasah Science Competition (MSC) held under the Ministry of Religion. In addition to aiming for the competition, this activity is on the other hand as a means of developing harmonization between religious sciences and the sciences according to the times and developing technology. This is in line with the opinion of Umar (2019) which was posted in a MSC activity report that the questions used in the MSC competition will be integrated with Islamic sciences. This is important to eliminate the dichotomy between general science and the science of religion, especially Islam [1].

The integration of religious sciences with science is not much different from the preservation of regional culture. Some skills in learning Javanese are commonly contested such as nembang, nggurit, and pidhato which are the basic subjects that are usually contested. While the material of Aksara Jawa is rarely contested in the school environment. Although some types of culture are contested, there is no place to compete in the madrasah. The competitions held at the madrasah level are usually only carried out on Musyawarah Guru Mata Pelajaran (MGMP). Whereas a special container as a means of successor to the steps of official school activities that are shaded by the government, especially for madrasah, does not yet exist.

This problem needs special attention from the local government, especially in efforts to preserve regional culture. This is noteworthy for education providers, especially for Ministry of Religion, which houses educational institutions such as madrasah. Schools that are under the auspices of the Ministry of Education, have begun to hold various race activities but have not become a regular agenda, while the madrassas have not started organizing activities/ events regarding cultural preservation. Madrasah with other public schools both have the same level and opportunity in preserving regional culture. So in this paper the authors convey what the conditions of the school are in the preservation of regional culture and the importance of conservation that must be carried out.

\section{RESEARCH METHOD}

This research is a qualitative research, using a case study approach, where the research is intended to describe, explain the results of analyzing phenomena, events, social activities, both individually and in groups. The data used in this study are qualitative data taken from various documents and informants as well as learning activities. Sampling in this study uses purposive sampling, directing sampling that is considered important and related to the discussion of researchers. Data is collected by interviews, observation, and documentation. Interviews are carried out simultaneously with observations sometimes carried out as a follow-up of observations or vice versa, and between interviews with documentation. Data that has been collected, the next stage is reviewing and compiling the results of interview transcripts, field notes, and the results of other data collection arranged systematically, looking for patterns and synthesizing [2], [3]. Next after knowing the pattern and synthesizing it, then conclusions can be drawn from the research conducted.

\section{RESULT AND DISCUSSION}

Aksara Jawa learning is one of the learning materials available at every level starting from Madrasah Ibtidaiyah (MI), Madrasah Tsanawiyah (MTs), and Madrasah Aliyah (MA). Learning Aksara Jawa at the level of Madrasah Ibtidaiyah (MI) began to be introduced with Aksara Jawa starting from class 3, namely with the introduction of sound and writing and reading words, at the level of Madrasah Tsanawiyah (MTs) began to be introduced to learn to read and write Aksara Jawas, and Madrasah Aliyah (MA) began to study Aksara Jawa with a more complex 
level, namely reading and writing Javanese lettered paragraphs [4]-[6]. The level of learning in each level of education has been measured by the ability of students. This is a form of strategy to deliver material efficiently in accordance with the capacity limits of each level [7]-[9].

The implementation of Aksara Jawa learning in madrasah has only been limited to giving material to students without any further steps after students carry out Aksara Jawa learning. Aksara Jawa learning at school not only introduces Aksara Jawa to the younger generation but maintains, and preserves Aksara Jawa relevantly in accordance with the times. As a small part of the identity of a nation that is owned by an area it should be maintained. Moreover, the Aksara Jawa where the script was used to write various works. Many literary works, inscriptions, histories, fibers are written using Aksara Jawa which contains a lot of history, science, various secrets that have not been revealed that happened in the past. Therefore, the importance of preserving Aksara Jawas for the younger generation, one of them is getting successors to uncover the secrets behind literary or historical works written using Aksara Jawa [10], [11].

The learning objectives with the implementation of learning that have been implemented so far do not seem to have been directed there. Some conditions seen in the field regarding the lack of madrasah support in the preservation of Aksara Jawa include.

\begin{tabular}{ll}
\hline No & \multicolumn{1}{c}{ Problems } \\
\hline 1. & $\begin{array}{l}\text { The learning objectives of Aksara Jawa are only limited to the achievement of } \\
\text { learning outcomes }\end{array}$ \\
\hline 2. & $\begin{array}{l}\text { Lack of socialization regarding the output of knowledge that can be utilized with } \\
\text { Aksara Jawa }\end{array}$ \\
\hline 3. & $\begin{array}{l}\text { There is no place, or advice that is prestigious for madrasah students as an excuse } \\
\text { to learn Aksara Jawa }\end{array}$ \\
\hline
\end{tabular}

First, teachers in the madrasah only prioritize students can achieve good learning outcomes, and can do the Semester Final Exam (UAS) well. In the implementation of learning in the madrasa, students are only limited to knowing the form of the Aksara Jawa, and some rules of writing. The teacher has not provided motivation regarding the things students can do for their future related to Aksara Jawa after students carry out Aksara Jawa learning. Motivation carried out by teachers when learning is more focused on how to foster interest in learning Javanese characters for students that are associated with Islamic values. When the initial activity of the teacher integrates a hadith regarding the intention to motivate students, the following quote.

"If someone in carrying out a thing intentionally because of Allah then what is aspired in the world will also enter in it, so that we will get reward and what we expect in the world we will also get [4].

The learning objectives reflected in the learning process are still limited to learning outcomes only, so that it does not include matters relating to the provision of debriefing to students in utilizing the knowledge to be learned (Aksara Jawa) to be used in future life later.

Second, lack of exposure to scientific output or employment on fields related to Javanese script in the mass media, or other social media. Lack of exposure to jobs related to Javanese script makes learning Javanese characters less valuable for students. Students do not have a view of what will be produced by learning Javanese script [6]. When compared with science subjects that are so flashy in the world of work, there is an imbalance between science subjects with Javanese. The lack of jobs related to Javanese script makes the learning less recommended to students. Whereas the graduates of the Regional Literature S1 Study Program are quite extensive 
and are available in various fields, such as literary and cultural researchers, literary translators and Javanese text editors, translators, Javanese journalists, host, Javanese culture-based entrepreneurs, creative writers, philologists. lecturers, practitioners of Javanese culture, and Javanese writers [8].

The role of mass media or social media now has a tremendous impact in channeling information to social media users. The power of social media to attract friends and followers gives the power to revive local culture, bring out cultural potential and preserve cultural values that have been fading up so that information about local culture can be easily obtained through social media. Social media is an important thing that has the advantage to be used by the community in efforts to preserve culture, inform local culture, and this potential can be explored if managed properly [8]. Based on this, if an institution or educational institution utilizes social media as an effort to mobilize the young generation in the effort of cultural preservation activities, one of which is Javanese script, then efforts to preserve Javanese script will develop towards a better.

Third, lack of containers or facilities for preserving Javanese script in the madrasa. Various activities or cultural events are one of the facilities as a place to introduce and preserve various regional cultures in an area. As expressed by the Disdikpora secretary, that the Education, Youth and Sports Agency (Disdikpora) of Denpasar City, Bali, held a Nyurat competition (writing) Balinese script. The competition in welcoming the $231^{\text {st }}$ Anniversary of Denpasar City was also held by an "accurate" Balinese script. This step also serves as cultural preservation, especially in writing Balinese scripts [12].

Based on the aforementioned things, competition or competition held specifically for the purpose of preserving a culture or incidentally as a means to redevelop regional culture can be used as a step for the government, especially the education and cultural services and the ministry of religion that houses educational institutions such as madrasah to support the preservation of Javanese characters as cultural property [13]-[15].

\section{CONCLUSIONS}

Based on the discussion above, it can be seen that Javanese script learning activities in madrasas are steps that are used as an effort to preserve Javanese script in educational institutions. Efforts made by the school include implementing methods, strategies, techniques, learning media that are appropriate to the situation and conditions of each madrasa so that learning can be delivered effectively and efficiently. In addition, there are three things that make Javanese script lack of action or further steps as an effort to preserve Javanese script in educational institutions under the Ministry of Religion, namely: 1) learning and implementation goals in madrasah are still limited to achieving learning outcomes, 2) Lack of socialization regarding the output of knowledge that can be utilized with Javanese script / exposure to Javanese script, and 3) There is no prestigious container or facility held regularly held by the Ministry of Religion. So there is no sense for madrasah students to learn continuously as an

excuse to learn Javanese script. Therefore, it is necessary to have input for the Ministry of Religion in an effort to support the revitalization of cultural wealth such as Javanese script as the identity of the region.

\section{REFERENCES}

[1] N. Ahid, "Konsep dan Teori Kurikulum dalam Dunia Pendidikan," Islam. J. Stud. Keislam., vol. 1, no. 1, pp. 12-29, 2006. 
[2] D. Rumahlatu, E. K. Huliselan, and J. Takaria, "An Analysis of the Readiness and Implementation of 2013 Curriculum in the West Part of Seram District, Maluku Province, Indonesia.," Int. J. Environ. Sci. Educ., vol. 11, no. 12, pp. 5662-5675, 2016.

[3] U. L. Yuhana and I. Kuswardayan, "Aplikasi Belajar Menulis Aksara Jawa Menggunakan Android,” J. Tek. ITS, vol. 2, no. 1, pp. A94-A98, 2013.

[4] P. Jateng, Kurikulum 2013 Muatan Lokal Bahasa Jawa. Indonesia, 2013.

[5] P. Jateng, Petunjuk Pelaksanaan Peraturan Daerah Provinsi Jawa Tengah No 9 tahun 2012 Tentang Bahasa, sastra, dan Aksara Jawa. Indonesia, 2012.

[6] P. Jateng, Petunjuk Pelaksanaan Peraturan Daerah Provinsi Jawa Tengah tentang Bahasa Sastra dan Aksara Jawa. Indonesia, 2013.

[7] Permendikbud, Standar Proses Pendidikan Dasar dan Menengah. Indonesia, 2013.

[8] Permendikbud, Standar Proses Pendidikan Dasar dan Menengah. Indonesia, 2016.

[9] Permendikbud, Standar Kompetensi Lulusan (SKL). Indonesia, 2013.

[10] S. Sutarsih, "Pembelajaran menulis Aksara Jawa anak kelas III Sekolah Dasar," Aksara, vol. 27, no. 1, pp. 65-72, 2015.

[11] G. H. Wibowo, R. Sigit, and A. Barakbah, "Javanese Character Feature Extraction Based on Shape Energy," Emit. Int. J. Eng. Technol., vol. 5, no. 1, pp. 154-169, 2017.

[12] N. L. G. R. P. Bintari, I. N. Sudiana, and I. B. Putrayasa, "Pembelajaran Bahasa Indonesia Berdasarkan Pendekatan Saintifik (Problem Based Learning) Sesuai Kurikulum 2013 di Kelas VII SMP Negeri 2 Amlapura,” J. Pendidik. dan Pembelajaran Bhs. Indones., vol. 3, no. 1, 2014.

[13] S. Sutjipto, "Pentingnya Pelatihan Kurikulum 2013 Bagi Guru," J. Pendidik. dan Kebud., vol. 1, no. 2, pp. 235-260, 2016.

[14] S. M. Wardoyo, “Teknik menulis puisi," Yogyakarta Graha Ilmu, vol. 13, no. 5, p. 0, 2013.

[15] W. S. Wulandari and S. Sumardi, "Pengelolaan Kurikulum Adadtaif Matematika pada Program Sekolah Cluster,” J. VARIDIKA, vol. 27, no. 2, pp. 152-161, 2015. 